\title{
One Thousand and One Coconuts: \\ Growing Memories in Southern \\ New Guinea
}

Nicholas Evans

\begin{abstract}
A
11 societies need methods of cultural memory, which, following David Berliner, we can define as "a synonym for cultural storage of the past: it is the reproduction of the past in the present, this accumulated past which acts on us and makes us act" $(2005,20 \mathrm{I})$. In Oceania, as elsewhere, the ongoing construction and reconstruction of personal and cultural memory draw on the external world (Forty and Küchler 1999; Stewart and Strathern 2000, 2003), with its stable objects onto which human talk and recall can fasten. But the external world offers different fastening points in different places, quite apart from the obvious technological contrast between societies with some form of writing, to record past events in the voices of the original recorders, and those that do not. In Oceania, there are cultural groups famed for monumentalism involving enduring constructions in stone, but, as Chris Ballard and Meredith Wilson argued (20I4), a full understanding of the mechanisms that cultures harness for memory requires consideration of a wider range of phenomena than the monuments that struck early European explorers in the Pacific as so spectacular. Pursuing their argument further means that all sorts of external elements, such as natural geological formations or arboreal features, must be considered if we are to have a complete and locally grounded account of how societies use the external world in the project of cultural memory (see Ballard; Kim, this issue).

In this article, I show how the Nen-speaking people of southern New Guinea use coconut palms to create an arboreal history anchored in the clear symbolic and practical intentions that accompany each planting. In a perpetually changing landscape without stable reference points, coconut palms offer the most durable means of keeping track of people's histories
\end{abstract}

The Contemporary Pacific, Volume 32, Number I, 72-96

(C) 2020 by University of Hawai'i Press

72 
throughout their lives and beyond through their lineages. By bringing in these particular Melanesian understandings and practices that differ significantly from the monumentalism and written records that dominate European and Asian cultures, I seek to overcome a gap in the quest by historian Reinhart Koselleck to understand the cultural and political embedding of how we construct historical time (2002, 2004). ${ }^{1}$

In many parts of New Guinea, ${ }^{2}$ such as the Duna-speaking areas of the Papua New Guinea Highlands (Stewart and Strathern 2000, 2003), landscape features such as cliffs, grasslands, and forest groves play a vital role in maintaining an "inner landscape of the mind," often through songs linked to place-names (see also Battaglia I990; Weiner I991; Rumsey and Weiner 200I; Lipset 20I4). Within the Morehead District discussed here, but about 200 kilometers to the west, there are thousands of identified places memorializing the ancestral past (Ayres I983), as well as the metaphorical use of two large trees-the sakr palm ${ }^{3}$ and the wasur ${ }^{4}$ strangler fig-as genealogical metaphors for representing, respectively, "lineal segmentation from a unity" and "scattering or fragmentation from a starting point or center" (Mary Ayres, as digested in Rumsey 200I, 28). And not far to the east, in the Purari delta area, trees are likewise important sites of history (Bell 2006). More generally, contributors to a volume edited by Joshua A Bell, Paige West, and Colin Filer have discussed the close links between Melanesian and other Pacific Island cultures and their forest environments (2015), and the collection of papers edited by Laura M Rival contains several studies of what trees mean across a range of cultures (I998).

However, these landscapes, and even the sakr and wasur trees discussed by Mary Ayres, largely preexist humans. The coconut trees I consider in this article, by contrast, bring together the phenomenon of memorialized landscapes, which are the product of biographically remembered human agency, with ceremonial objects, whose association with ancestors and place making in the landscape has also been widely explored (eg, Weiner I99I), though they are not part of the landscape. Coconut trees, in other words, are part of the landscape, but at the same time they are almost invariably the result of a specific act by a known, named individual. My goal, then, is to consider how one form of other-than-human entity-the coconut palm-is used to create and maintain memories, including memories of intentions and pledges for the future, thus creating a link between a human and a growing, nonhuman element of the landscape from the moment it is planted. 
Nen is a language of the Yam family with around 350 speakers (Evans and others 2017), bordered to its west by the closely related Nmbo (also spelled Nambo) and to its east by the unrelated Idi. The various languages are closely integrated into a single cultural bloc, knitted together by sister exchange, shared ceremonies, and section systems, with widespread "egalitarian multilingualism" (Haudricourt I96I; François 20I2). Nen speakers, whose various clans belong to the Äkämära tribe, are culturally similar to the "Kerakie tribe" described in Francis E Williams's classic ethnography (1936). ${ }^{5}$ The societies of the Morehead District remain largely customary in the material aspects of their lifestyle, despite the incursion of evangelical Christianity since around I980 (primarily the Evangelical Church of Papua New Guinea). They live as subsistence farmers, with yams, cassava, sago, and bananas being the main staples, supplemented by hunting (especially cassowary, deer, wallabies, wild pigs, and bandicoots). Despite the ubiquity of coconuts in the region, and in contrast to many other parts of the Pacific, ${ }^{6}$ copra is not produced.

\section{Researching Growing Memories}

My analysis draws on interviews carried out with and by speakers of Nen, Nmbo, and Idi in the village of Bimadbn and its neighbors (map I), using whichever language(s) people felt happiest speaking. Collating these accounts provides a detailed picture of how people of the region use coconut palms. Perhaps more importantly, they illustrate how far people, in planting what are the most enduring human elements in a shifting landscape, plan the reception and witness that these plants will bear down through the generations.

This interview material grows out of longstanding linguistic research in the Morehead District (see Evans and others 2017). More recently, the region's exuberant linguistic diversity has made it a key case-study site in our project titled "The Wellsprings of Linguistic Diversity," which seeks to understand the dynamics of how linguistic diversity arises, focusing particularly on naturalistic speech. To that end, the data gathered spans many topics of cultural interest: customary stories, disputes, hunting and gardening, and juridical treatises on the rules of sister exchange, widow remarriage, and other such arrangements.

In addition to these, though, we needed a common yardstick, a topic that individuals can talk about in an animated fashion, so as to gain a sample of unmonitored natural speech on a topic bringing in discussions 


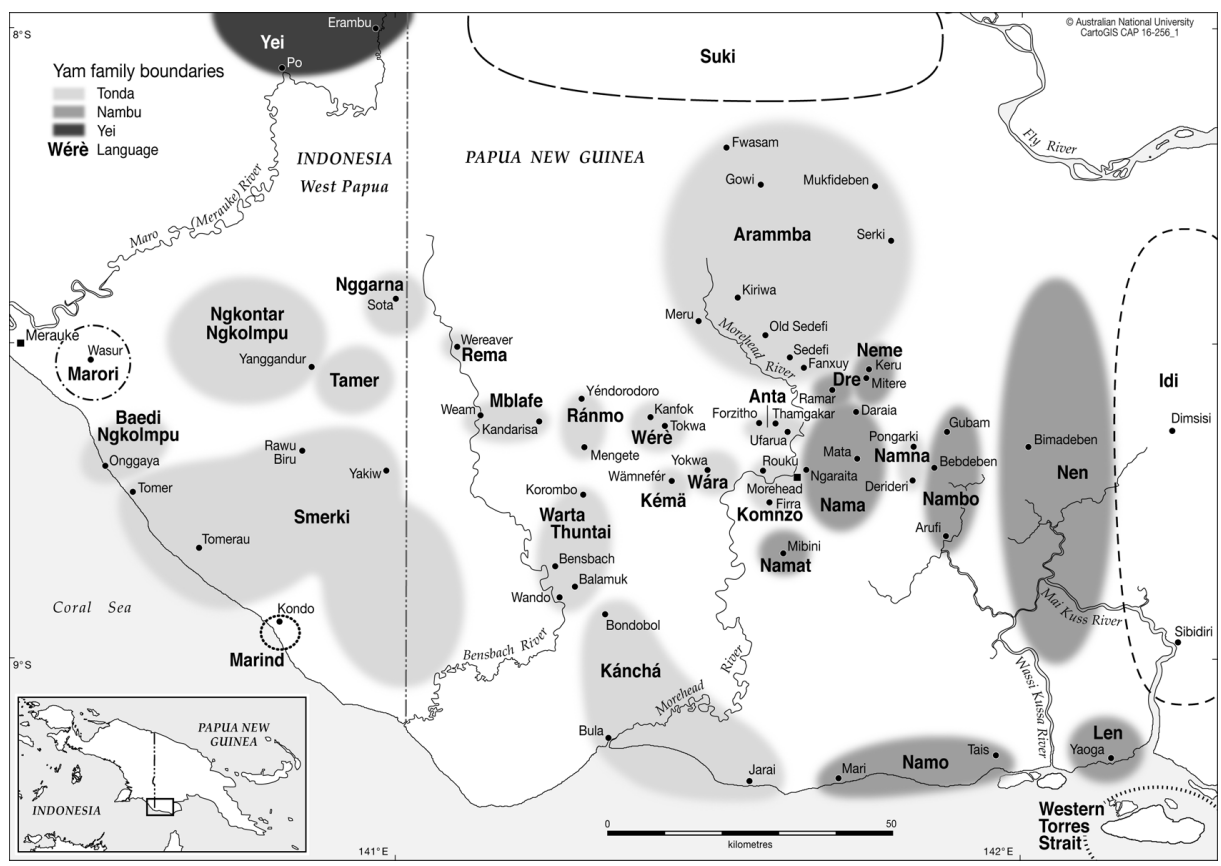

MAP I Languages of the Morehead District. Commissioned by Nicholas Evans. Copyright the Australian National University, College of Asia and the Pacific, CartoGIS.

of social relationships and places. Since my first field trip in 2008, people had drawn my attention to the memorious significance of particular coconut palm trees (see Harrison 2004 on the notion of "memorious" landscapes). More specifically, the topic of coconuts was chosen because:

(a) coconut trees are highly salient, tied to individuals, and record up to a century of history across villages, gardens, and bush; ${ }^{7}$

(b) almost everyone has stories to tell about trees that they have personal connections to;

(c) it allows discussion over the full range of tenses, from remote pasts (eg, who planted them and why) to recent pasts (eg, accounts of a just-planted coconut), generic presents (eg, what they can be used for), and the future (eg, intentions), as well as such modal twists as negatives (coconuts that no longer exist) and hypothetical or irrealis moods (eg, what would have happened had the coconut not been destroyed); and 
(d) for each coconut there is a clear notion of who has the right to talk about it, and almost everyone has at least one coconut palm to which they bear a special relation, making it a natural way to give everyone a voice in a survey concerned with fathoming the full range of linguistic variation in a community.

At the community's suggestion, we organized our work in the following way. Each clan had a "language committee" (two men plus two women) who were trained to make sound and video recordings and carry out interviews. Since these committees could include in-married spouses (who count as clan members), not everyone was a native Nen speaker. Each interview was carried out by a member of the language committee, with sound recordings made by a third person and video by a fourth.

My project colleagues in neighboring villages-Eri Kashima in the Nmbo-speaking villages and Dineke Schokkin in the Idi-speaking onesworked in parallel. Because many people move villages on marriage, all team members oversaw some interviews in villages of neighboring groups. Interviewers were encouraged to explore whatever topics they felt relevant. Overall, I recorded over 70 coconut interviews ( 12 transcribed in detail), including 8 with parallel Nen and Idi versions and 4 with parallel Nen and Nambu versions. ${ }^{8}$ Of these, 6 are language asymmetric (ie, the questions are in one language and the answers in another); this always arose spontaneously through choices made by speakers about the languages they were most comfortable with. In addition to my recordings, project members Kashima and Schokkin recorded another 30 interviews.

\section{Amnesia of the Landscape}

The physical environment of the Morehead District is a mix of landscape types distinguished emically in Nen as pan (savannah); wrng [wərəng] (rain forest, "bush" in local English); ${ }^{9}$ pupui (riverine swampland); and sao (terrestrial swampland, heath), as well as kkp [kəkəp] (garden) and samba (village[s], areas cleared for habitation). It is entirely devoid of permanent physical features, such as rocks and cliffs, which anchor external memory in such parts of the world as Indigenous Australia (Morphy 1995), New Caledonia (Horowitz 200I), and the Peruvian Amazon (Santos-Granero I998). The houses—of wood, bark, and cane-rarely last more than ten years, after which they are recycled and often resited.

Likewise, gardens are temporary clearings in the rain forest. In the first 
stage of their life cycle ( $\bar{g}$ ayag, or "new garden"), the bush is cleared, or $r t s$, by slashing and burning, and the area is fenced in to keep out pigs and deer. Once fencing is complete and people have begun planting, it is referred to as $k k p$ (first-year garden). These terms are only used for gardens cleared in the forest: people also have small back gardens, or $z u z u$, behind their houses in the village where they grow bananas, fruit trees, and other plants.

In the first year after clearing the forest, yams are planted to take advantage of the more fertile soil created by burning. A small garden house is built, and some coconuts, cassava, and bananas are also planted. By the second year ( $g \ddot{a} t k r$, or "second-year garden"), the soil is less fertile, so the main plantings are cassava, bananas, and pineapples; the young coconuts continue to grow. By the fourth or fifth year ( $d u$, or "old garden place that still has some bananas and cassavas for harvesting"), plantings cease, and the fences are dismantled for firewood. Former garden sites are known as tendewere $k k p$ gät $k r$ (abandoned garden from long ago). The forest steadily grows back, but the coconuts remain as a reminder of the garden that once stood there (such former gardens are, by this stage, known as $d u d u)$. Those who had worked in the garden in their youth retain knowledge of those coconut palms-often requiring off-track navigation to reach-and can recall the circumstances of their planting. ${ }^{10}$

Other ecozones are also constantly changing, this time without human intervention. The boundary between wrng and pan is itself unstable, with the former encroaching on the latter unless efforts are made to burn back its edges, and many people have told me that the rain forest has extended its domain during their lifetimes. Various terms focus on the results of this dynamic interplay: mnzmnz are small patches of bush in the middle of the savannah, pan qép is a patch of savannah surrounded by rain forest, and wae is a tongue of savannah intruding into the bush, typically remnant savannah where bush is growing back on both sides. The environment thus supplies a "forgetful" rather than a "memorious" landscape, to use Simon Harrison's terms (2004).

However, unlike the Sepik (Manambu) case that Harrison described, in which humans aided the environment in the forgetting process, the practice of planting coconuts helps to hold back the amnesia of the landscape. ${ }^{11}$ There are thousands of coconuts in the district-old coconuts growing amid the rain forest as the only surviving evidence of an overgrown garden (figure I), a row of palms marking the site of an abandoned village, or younger coconuts standing in a currently inhabited village. But there 
is usually someone to whom they can serve as a prompt for a detailed recounting of the memories they evoke.

\section{Uses of Coconuts}

Coconuts have been called "the tree with a thousand domestic uses" (Caillon 20II, 344; in a Vanuatu context), ${ }^{12}$ and their uses in southern New Guinea are multifarious. ${ }^{13}$ I will not outline all of them but merely mention those that came up in the coconut interviews. In these contexts, the material presented pertains to general lore about ceremonials, and procedural knowledge about their uses, rather than any specific memories related to individual trees.

Any new arrival in a village is greeted with an invitation to drink the juice of a fresh coconut. Often the job of knocking down coconuts for drinking is delegated to children or youths, but men and women right up to middle age still climb:

OK gta aga glä ada yi yibeñin ada ... wot bdegawa yi ddre gaita gl bträñ. OK bo mo koa ne tm nänäwä gl bkরio bo glä yi dabe. Tm nänäwä.

(I planted this coconut . . . for cooking, I will pick the dry nuts. If I want to climb up, I will climb my own coconut. Green ones, for drinking.) (Thithy Masa, in Idi; CR I 8$)^{14}$

Food derived from coconuts is used in daily, secular ways (eg, basyao gravy, in which yams, pumpkins, and other foods are cooked). But it is also an important part of several ceremonial foods, such as the special skr, tm, and tortor puddings, in which yams are mixed with scraped coconut flesh and wrapped in banana leaves to make giant logs that are baked on hot coals:

$S k r$, tortor, tm, yande waprs yam bä bä ym, mingane tm dene nambt ynao tm trtam dmabem ynao tnetam yergban gte, ynagta, skrta, skr dene ynao yngdäbtam totr ämb yngnetam, a totr bm, ynd mäpna ynm yao tstam tortor yna agngama, ybe amabem dstawt dedabem. Daprtawt ybende waprs yam bä bä dnzron, ẽ totr ärm yao yaprtam yna yam, nu gs ymn nu dene äte dnzron, nungama bä dgmenganzt, ag ä dngdronawt, nuwama, ynamnewama agngama dngdronawt ynangama.

(Festive yam logs, shell-scraped yam logs, purple yam cake, that's what it's used for. That purple yam cake which we made a few days ago and which we ladies ate by the riverside, for that and for yam logs, we still eat them nowa- 


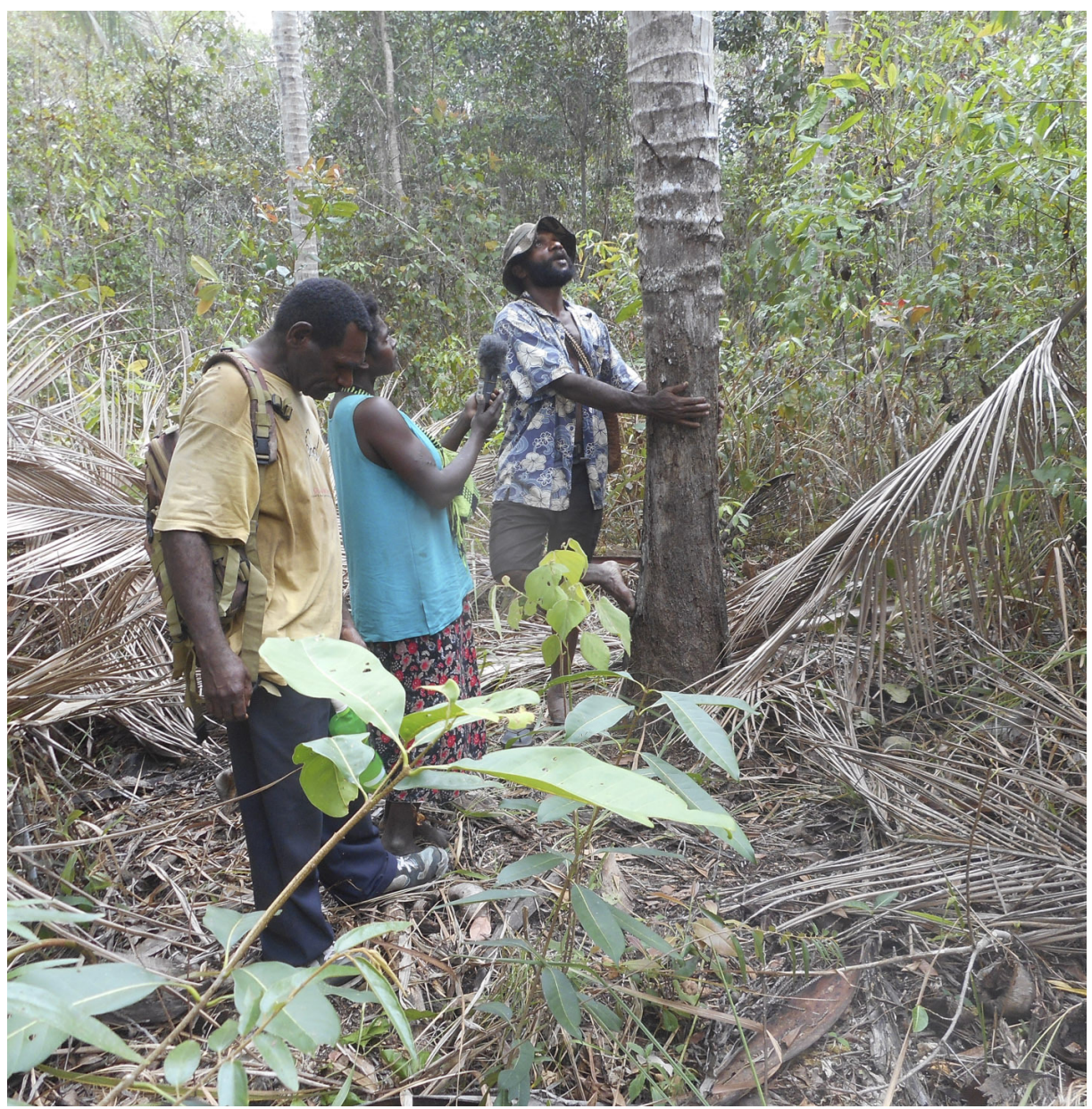

Figure I Goe Dibod (right) being interviewed by Srgo Daiba (center) next to a coconut in an overgrown garden site. On the left is Jimmy Nébni. Photo by Nicholas Evans.

days. We don't know, we haven't made a shell-scraped yam log from these coconuts. It was our mothers and fathers who used to scrape that yam with a shell. Younger generations don't do that custom. The juice of the coconut, they used to pound [the tortor] with [coconut] water, they used to squeeze it on, with that scraped coconut they would pour it on the base and squeeze the cream [onto the purple yam cake].) (Sambo Saoda, in Nen; CR47)

Dried fronds and frond netting are used for fire, especially as bright torches to illuminate dancing at night: 
Simne ymn, anganan yna siba bä, déngiwirmde drmnawt, ä dizernganzt ynane. Waprs yam bä bä dngnzron.

(It's for light, when dancing [at night] they would light these, as they were dancing and encourage each other on. That was their custom.) (Sambo Saoda, in Nen, interviewed by Geroma Rami; CR47)

The fronds are also laid out to sit or lie on, and the coconut fiber is used in baskets and decorative hangings at festivals and burned as garden fertilizer. The palms are tapped to yield a sweet substance fermented for tuba (palm toddy), coconut halves are used as impromptu cups, and stunted coconuts (ag supi) are used as ocarina flutes.

This is only an incomplete survey of some of the uses mentioned in our interviews-others described by Williams for the neighboring Keraki include drinking vessels, woven mats, coconut-leaf bull-roarers, and phallocrypts (I936, 435, 432-433, 44I-442, 396). Unlike the Marind-Anim peoples a couple of hundred kilometers to the west, I have never heard mention of uses of coconuts comparable to those documented by Jan van Baal (I966) and reported by Bruce M Knauft (I993, I40-I43, I 50-I 52, I6I, I79), in which coconuts are connected to heads and used in various rituals. I now move on to the role of coconuts in maintaining memory, as physical witnesses to the acts of planting and their subsequent association with one or more specific people who can call on them as anchors to their accounts of the past.

\section{Plants and Memory}

The use of plants to validate clans' ancestral claims to land is widespread among the peoples of the Morehead District. The presence of particular plants is attributed to ancestors who planted them there, though too far back for direct descent to be claimed. Many villages are named after particular plants, with each plant's name compounded with the word meaning "stem." Thus, the rattan cane (Corthalsia zippellii), which is called bima in Nen, gives the village name Bimadbn ("rattan stem"). Likewise, the village name Bebedeben/Bevdvn, which was the focus of Williams's ethnographic research and now Eri Kashima's linguistic work, attaches the Nambu root deven (stem) to the root bebelbev (breadfruit) (béb in Nen). ${ }^{15}$ Visitors are taken to see the plant that gives its name to the village, a process that establishes the claim to clan ownership by the guide, and 
the group to which they belong, by showing their deep knowledge of the locale's history.

Among the trees whose planting by named humans is remembered, the most important are sago and coconuts. Sago is economically important, both as a reserve food and as a bequest to one's descendants that takes several decades to mature, but it has far fewer symbolic uses than coconuts, and it is not planted in villages or public places where individual plants can form daily prompts to memorious discourse.

\section{Coconuts as Genealogical Investments}

Interpretations of what coconut palms mean from the perspective of interviewees are inevitably oriented toward memory. But at the moment of planting itself, the temporal orientation is strongly focused on the future, often as a practical and symbolic investment in the planter's children's futures.

A good way to understand the symbolic importance of coconut planting is to consider how they are planted by newcomers to the village, typically in-married spouses. This combines a pragmatic self-sufficiency-planting for one's children and grandchildren-with a claim to one's right to be in the village, especially through one's male descendants. ${ }^{16}$ Consider the account given by Gvae Nézén, an in-married man who had to remain in Bimadbn because he could not get a second exchange sister for his second wife (figure 2). His clan had given him an exchange sister for his first wife, but when he wanted another exchange sister to take on a second wife, they refused. Because of this, following custom, he had to stay in the second wife's village. As he told his son Daniel in an interview:

Ynd äte yiwin yna ag a, eighty-eight, mnedbnan yiwin gehẽ, tande nneta, geä ynetan togetoge bm dawakatawn, ka ärbende ag yao bä yngbrnan zi ba yngm, tanzo agma itan, ynadbnan ä dngitawn. togetoge bm tawakatawn, de kaba togam na ag bä ynetat kitong geä yäwämteta. OK pi ynadbnan yiywin. gi yiwin ag dängwayabtawn. Gngoyabtawn togetogeäbet begta bä ym begta bä ym begta bä ym.

(I planted this coconut in eighty eight. I planted it here because ... for my own food, if I eat it, I was thinking of you my children, it wouldn't be good if my children knock other people's coconuts, otherwise people will say bad things about them, for that reason I planted my own coconuts. I was considering all of you, what coconut will the children eat when they are all fully grown? That's the reason I planted it. I used to show the coconuts to the children and 
[say to them] this is yours, this is yours, this is yours.) (Gvae Nézén, in Nen; CRI 5 )

Likewise, but this time from the perspective of an in-married woman, Rusien Aniba explained why she planted a coconut on arrival in Bimadbn:

Ynd yna ag yna gi yiwin, mnegta yiwin, tande ämkpan dene dnzron ynd gés qnm Aropengama dmabta ynat ynd ta toge geä déngingn, yna togam geym ä ynetat tande yna ag, yndbem ärgäde togetogeyaba ä bä ynetam gtets ynd kr geä wm yna ag ägorngn tande togam ä ybrne powa keseren Zoelm yna ag, o yande togetogeyäm, dene ämkpan yiwin ynd yna ag.

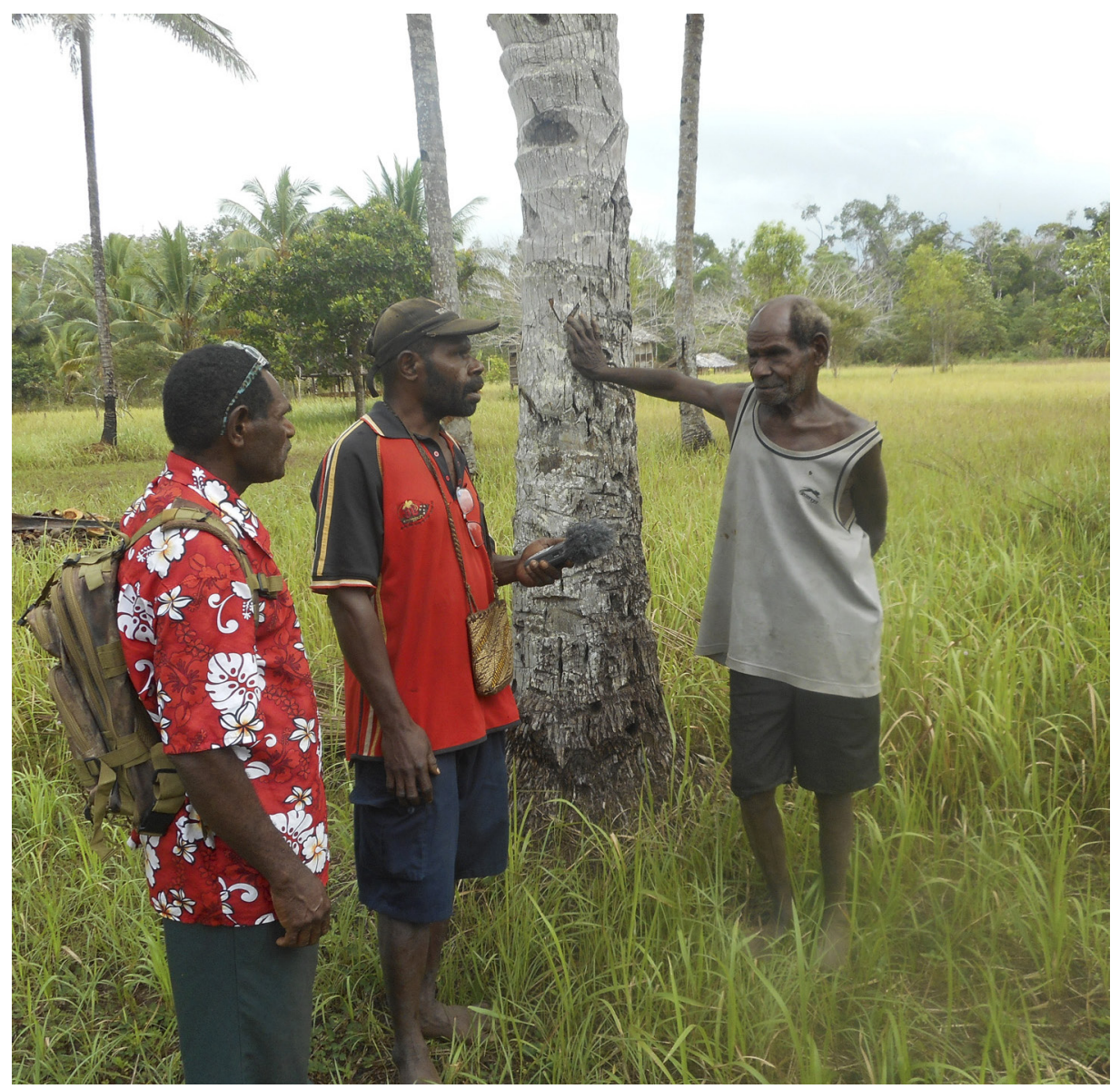

Figure 2 Gvae Nézén (right) being interviewed by his son Daniel Gvae (center). Photo by Nicholas Evans. 
(I planted this coconut here, the reason I planted it, my idea was like this, when I came from Arufi and got married here, I should plant a coconut to have coconut to eat, if I should have myself a child, this child will . . . and they will have this coconut of mine to eat, we will eat these together with our children, till I die, I will leave this coconut, and my son Joel will knock this coconut in days to come, or his children, with that idea I planted this.) (in Nen; CR38)

Unfortunately for her, in this case her plans were derailed due to the following circumstances:

Wndede totr yna ag tande yna yao ym, mnene yna yao ym? Yäl yrniwindt togetogeyäm wrngt Ynd gowabtawn dämbronawn "bmbem neita tande mleg neita wrngt yrnindt? tande mleg mng är tnanğtang!" Yna togetoge dänzron néqéba nämtewend tande ziwan, tande ag yñpawend dgane ynd yta yiwin tande togat. Ta bas ynd geä dnetawn yna ag. Wndede ymabem yna ag.

Mnene tande togande bandan ynd yna ag yiwin yñpawend tande. Ynd ynadbnan totr uséspner wm. Mnegta ynd yna agan ä gäbentawn tande toge ä yanzo bandan ynd yiwin yna ag.

(But now this coconut of mine is not here, why isn't it here? [My daughter] Yäl was taken away by boys into the bush. I spoke to them and quarreled with them, "why did you people abduct my daughter into the bush? Bring my girl back right away!" These boys got angry at my words. They cut my coconut which I had planted for my daughter. And for myself too. I should have been eating the fruits of that coconut.

But they cut the coconut of mine. Because of that I am unhappy. Because I planted this coconut in my child's land. Because I was depending for food on this coconut and my child too, that is why I planted it in my child's land.) (Rusien Aniba, in Nen; CR3 8, continued)

Since daughters normally leave the village when they marry, parents make different assessments of whether to plant coconuts depending on whether they have sons or daughters, as recounted by Sambo Saoda, a Bimadbn woman who ended up staying in the village of her birth after marriage despite her parents' expectations:

Yande awabaes kitong deneta bä dnzron, dede bä ämb taeman dene amam dene bä gawaete . . . bbende dede ge dnzron bä yao mũte dnzron dene, ag o bi geä déngiti mnene, bm mlegs dawakate, mnene yande embärs dene dnzron yna, är sakr geä dnzron mlegmleg powa keseren geym ä yengewelmän ämb sambat ärba bä yngäwämtete. Är sakr geä dnzron, ymam ag bi tärbär ä diti, ynadbnan yande ag prap gs ymn, yna awabaesn dnzron, dede, ymam powa bä 
yngazne yna ag, dene dnzron yande ämkp, mnene ynd má mlegs dnnzron, mm ypale de är sakr geä dngnzron, ymam ag gbres tärbär bä diti, yande bäs ym.

([My father's] main concern was, as my mother told me one time, it was your father who didn't want to plant coconut or sago, because he saw you just as girls, later on these girls will go off to other villages and get married. If there had been a boy, he would have planted lots of coconuts and sago. Because of that, unfortunately his coconut over there, according to his thoughts, father, "Who would get all these coconuts?" That was his idea, because we were just girls. If there had been boys, he would have planted a whole lot of coconuts. This is only one.) (in Nen; CR47)

The use of coconut planting as a genealogical investment-by in-married spouses, either men (Guvae) or women (Rusien), or by parents dwelling in the village (Sambo's father) - is a practical resource-securing expedient and a claim of belonging, both for the planters and for their children. Such plantings secure their claims by deliberately creating public, social memories in the concrete form of a coconut tree and in a particular location that unmistakably renews the memories of others on a regular basis. However, these acts are not guaranteed to produce lasting effects, and, as Rusien's case shows, aggression by others can sever such genealogical claims to the future.

\section{Coconuts and Autobiographical Memory}

Coconuts may also be planted for reasons other than staking territorial claims. When this happens, their presence often acts as a reminder of particular episodes in people's lives that led to the circumstances of their planting. Consider this excerpt from Sambo Saoda, this time talking about a different coconut tree from the one discussed in the previous excerpt:

SAmbo SAOda (in Nen): Yna ag gs ym, Blag Aropet dngzron, Aropengama ge gnangte Boetan ynanewe yna ag. Ynat dnrenze. ynd dene wmtewe dene. Sambo! Yna ag geym bä ti mnegta togepner ä kämte, mnene tbende toge tärbär dngnzron. Yna ag ynd ge yiwin, tande toge pigta ynd yiwin. Yna ks yam ge yanewe, enzne ge yanewen, yna pétiba yiwin, yna ag mnegta dene ynd toge pi bä wm.

GEROMA RAmi (in Nen): Pitas ym yna ag ä ybrne?

SAMBO SAODA (in Nen): Ynd ag yndbem ynetam.

(SAmbo SAODA: This coconut here: Blag by that time had gone to Arufi. When he was coming back from Arufi he got this coconut in Boite and brought it 
here. He told me: "Sambo! Plant this coconut so you will stop having children. Because we have plenty of children." This coconut I planted, I planted it because I had enough children. I had my periods, I was sick, I planted [my] grass skirt [which I was wearing during my period] with the coconut. This coconut was so that I would stop having children. ${ }^{17}$

GEROMA RAMI: Is it OK for you to knock these coconuts down?

SAMBO SAODA: This coconut, we are eating it.) (CR2O)

Important to this autobiographical memory are relationships with others who facilitated the planting. People do not just remember when they planted a coconut but also who gave it to them and where it was brought from, as shown in this interview with Thithy Masa by Ymta Sobae:

YмтA (in Nen): OK ämb zigot ä génémtangn aqa dene dgaemne ag bm ynane ynkapawe yna ge yiwi geym?

тнітну (in Idi): Gta aga glä doat da Kennethbänä single taemat aga obo dawaye OK gta aga dederä daliata gukumema gämä gibänänim.

(YMTA: OK I'm going to ask you another question like this: Where did you get this coconut that you planted here?

THIтнY: These coconuts are from Kenneth [her husband] when he was single and I brought the dry nuts and planted them.) (CRI 8 )

The uses discussed in this section deal largely with "private memories"-perhaps others witnessed the planting, but the vital thing is what the person who planted the coconut remembers rather than any public contract, as was the case with the genealogical investments discussed earlier. But I now turn to a much more public way in which coconut plantings function as public pledges with important consequences through time.

\section{Coconuts and Collective Memory through Public Pledges (Tab)}

The word tab means "sign" and can be used in a variety of contexts, such as when tying a piece of bark to a sapling beside a path to signal that a dangerous snake resides in a nearby hollow log, or when leaving a branch of a plant symbolizing one's own clan to indicate the direction taken along a path. But tab can also refer to a more public memorandum accompanied by a verbal commitment, typically a pledge, wish, or reconciliation. For example, when the community of Bimadbn committed to building a house to accommodate me in the village, I had to plant a coco- 
nut and make an appropriate speech promising to work long-term on the language. Another time, a visitor from another language group planted a coconut in my yard to remind me of a pledge I had made to find someone to work on their language.

A special type of tab pledge was used as a way of settling disputes:

Yna zi ä yaetan kakekakeyäb denngama obengama ge gngägmetawt, denngama kérbér gelawanganz mnegta aqa yao bä gägmt obengama. Yna ag geym ẽ, a tbende keseren tm. OK är bolo dnzron Wenembu. Dimsisimne är dnzron Masro, ymam obe zi dmtete. ... Yna taeman Rami mamos dnzron, bä ymam yna kot daprte.

(I'll tell this story of how our ancestors fought with sorcery, and how peace ["coolness"] would come in, so that they wouldn't fight with sorcery again. This coconut here was [planted] in our time. There was an old man, Wenembu. And there was a man from Dimsisi, Masro, who accused him of sorcery.... At that time Rami was the village chief, he was the one handling the case.) (Warapa Wlila, in Nen, interviewed by Jimmy Nébni; CR77)

As the disputants pledge to let their ill feelings drop, saragao, a wild ginger (Amomum aculeatum), is planted in such a way that it will grow up winding around the freshly planted coconut. This is done in the presence of as many people as possible:

JIMMY NÉBNI (in Nen): Snamb mrkp ärm yna ag yésén, saragawaba ge yiwind? Snamb mrkp ärm dakatawt yna ag yésén?

WARAPA WLILA (in Nen): Ynd yna mrkp yna gs ynm dene Sangara wa Kiembtuwirer, Seregu mne gs dänzron, yna Erbowag gs dänzron, Nängbläg gs yäm, $\bar{g}$ mande är bolo yna dnzron.

(JIMMY NÉBNI : How many clan groups planted the wild ginger with the coconut? How many clansmen watched the coconut being planted?

WARAPA WLILA: We were there with these clan groups like Sangara and Kiembtuwirer, also from Seregu, and Erbowags were there. There were Nängblägs, Ḡma's old husband was here.) (CR77)

The wild ginger is chewed, and one disputant spits the mix onto the other's chest. The person doing the spitting pledges not to take revenge or to hold a grudge despite earlier unfair accusations:

Yna sarawaga, ge ge dapert eee, Wenembum dene ymtewe: "Mer ym, Sarawagangama má znse bä nzntan, mne bende ypales yam o yam dene, yao ymam qgmete, nen ym, sarawaga." 
Ynanewend ros yapapwend, mnegta drte äbrete bä gämtenga aqa snngama powa bä ybämte. Yna är bolo gs ym yna ärei yabenewe. ... Sarawaga erewe dbämte. Bä bä tikpei, tikpama yna sarawaga nungama, dabene dramte dznte dene geä, powa yao bä ngmetan, mnene "Ynd bm obe zi gs wmtete m ograesngama bä sarawaga ybämtan ä gs ym e. powa yao qmte ynd ge obe mäpna wm.". . Y Yndbem prende bmbem prende ymabem prende Wenembum prende dznte. Sarawaga a ag gs ym totr ä dingm, mnegta ä dingm powa obengama yna nägmetam, ynadbnan bä ym sarawagangama gbres ä̈ näzntam, yna makba bä gämtengm.

Ynangama wnde aqa nägärn $\square$ we wnde aqa ymam dnznte. Powa obe zi yao bä gämtand, yao pip. Mnene yna rokar gym kérbér rokar ym sarawaga gym kérbérba ym, yna mur yam ymam bä yaprte saragawawem.

(This native ginger, as they were settling things, Wenembu said like: "Good, I'll chew this ginger and spit at you, because you're putting your trust that I have not been killing you [literally: 'putting your trust: he has not been killing me']."

They brought it and started beating it so that it'd get soft; afterward they'd chew it with their teeth. That old man, he gave it to that man.... He held the ginger and chewed it. With this [spit] on his chest, he'd spit on his chest, he'd pour it on him and spit it, "Henceforth I won't kill you, for accusing me of being a sorcerer, telling lies, I'll chew this ginger, here I am. Henceforth, you won't accuse me. I don't know how to do sorcery." ... We brought the coconut and all stood around. Wenembu was spitting at him, saying: "From now on I won't kill you. I am just making you wet with ginger, I'm sorry, about these words [you] were saying, I am not a sorcerer, as you accused me.”... We, then you, then they, then Wenembu all spat [out the chewed ginger] then. This wild ginger and coconut here, we planted it after that quarrel over sorcery business, so that after that we would stop killing each other over sorcery. That is why we spat at each other with wild ginger juice, we would all have this mark of commemoration.

From then on they would not accuse each other of sorcery, not at all. Because this thing is a thing of coolness, this wild ginger brings peace.) (Warapa Wlila, in Nen, interviewed by Jimmy Nébni; CR77)

Then a dry coconut is planted, and as it grows, it stands as a testimony reminding everyone of both the past dispute and the fact that it had been settled. Unlike other coconuts, palms planted in this way become common property, and anyone can harvest their fruit:

Ag ge dinganzt dbnba geä dnrpanganzm, ä dinganzm ag kakawan, mnegta ä dbarnganz yna. yna sarawagaba ag gs yindm, yna ag bä ym gbres ärt. yao är bä nowabte yna ag geä ybrnat, yao bä ynd gowabta pri ym, pablik ym yna ag ge ym, mñtengama, yna yésmne bä ym, bm ebe te nnam, bä te nngangobrna. 
(This coconut, which we planted with the ginger, this coconut is for everyone. No one will say anything when people are knocking down its fruit, I will not say anything, it is free, it's public, that coconut. It's free, this one that has been planted, whoever comes, go ahead and knock plenty down.) (Warapa Wlila, in Nen, interviewed by Jimmy Nébni; CR77)

While public pledges accompany a number of $t a b$ rituals, the $t a b$ ritual described earlier combines many elements not found in other coconut plantings. The dual planting that joins the "coolness" of the wild ginger plant (a symbol of peace, as opposed to the heat of anger) with the longevity of the coconut palm (a permanent reminder) requires widespread witnessing. ${ }^{18}$ This is because of the importance of ensuring that all are party to the dispute resolution, to the participatory aspect involving the spitting of the cool ginger pulp, and to the availability of the coconuts grown on the tree to whoever wants them, unlike the proprietary nature of most coconuts. These aspects distinguish the practices surrounding these tab from those surrounding other coconut plantings. And this makes it a particularly good example of ritualized memorialization through planting.

\section{Disputes about Coconuts}

Coconut palms, however, are not always mediators for peace. In various disputes, aggression is directed against coconuts-with offended parties destroying them or burning them down and those visited with such aggression often lamenting that this prevents the fulfillment of their earlier wishes. This was the case in Rusien's story, recounted earlier, in which young men who were angry at her for demanding her daughter back vandalized the coconut she had planted to signal her move to the village of Bimadbn and to provide for her children's needs. In the following, more extreme case, a prior conflict over accusations of stealing led to a revenge attack on coconut trees and other property:

Yna är gowabtanga dene, deneyam gbres bä yaprtam, prende Dumsu, Dumsun gbres, qérqérngama ag dknawt, Dumsun gbres, mämä däwämtete daope, gbres gagu dawapane, daoroe deneyames yänzrman. Ag dgaemne dngnzron, ämb ag totr yés dngnzron yta tbende gbres ynane dngñptawt yna Erbowag är mrn ärbende tbende.

(This man spoke like this, this is what we all will do, first Dumsu, everything in Dumsu, they set fire to all the coconuts, all the coconuts in Dumsu, they spoiled them all, they all got burned, all the trunks fell down, they all shrank. 
All those coconuts which were there, and others which were newly planted of ours, of all the Erbowag clan people, all ours, they cut them all down.) (Joshua Wenembu Minung, in Nen, interviewed by Kandr Sobae; IR I)

Of course, this is not unique to coconuts-it can also apply to yams, yam houses, and other plants and related property. When the anger is less extreme, or the aggressor is restrained by someone else, the trunk is simply chopped without the whole tree being destroyed. In this case, it is the chopping marks on the coconut rather than the tree itself that carry the memory of the dispute. All can see them, yet, unlike with plantings, the act of inflicting them may have been carried out unwitnessed. This may necessitate discrete inquiries to find out both who made the cuts and what the grievance was. Things may simply be left at that, or appropriate moves to recompense and reconcile may be made.

Generally, then, coconuts play a crucial symbolic role in carrying forward long-standing commitments from the past, provided they remain undisturbed for their full lifetimes of many score years. But the past is not an undisputed land, and arguments may see the trees either cut or burned down completely, negating the purpose for which they were planted, ${ }^{19}$ or left alive but scarred to carry forward the memory of grievance.

\section{Conclusions}

Coconuts, as we have seen, play a central role as memories and witnesses of the past and as links between individuals and places. Among plants, they are not unique in this role. As I discussed earlier, most villages have founder plants, such as rattan vines, breadfruit, or stands of bamboo, that they are named after and that are shown to visitors to demonstrate the ancestral origins of the village. These plants, however, are believed to date from a much earlier epoch. Sago stands, with their harvest cycle of many decades, also memorialize the landscape in the sense that each person who plants them is known and tracked (particularly since knowing who planted them determines who can use them), but I have not heard of them being turned to the more social and biographical uses that I have discussed here for coconuts.

Memory building through the practice of planting coconuts blends intentional and unintentional aspects. In the moment of planting, people plant coconuts both for later use and for intentional communication with those who are there to witness, as well as with the more temporally remote 
audiences to whom the circumstances of planting will later be recounted. Thus, the planting of a tab coconut palm, symbolizing reconciliation between disputing parties, immediately communicates the cessation of grievance between the parties, calls on those present at the planting to witness, and establishes a promise to those who will regard the coconut later in time that its fruits will be available to all. This promise is mediated by the memories of those present at the original tab ceremony and transmitted to and through their descendants.

These acts of planting link the past to the future. Kakekake means "great-grandkin"-and just as this kin term can count backward to greatgrandparents and forward to great-grandchildren, the future intentions and commitments at the time of planting are remembered as past deeds when beholding the grown coconut. Thus, depending on where it is in its life cycle, the coconut serves as a form of communication with those who will come after, as an external aid to memory, or as proof of what happened long ago.

At the same time, as they grow, they come to be ancient and uninterrogable witnesses in the landscape. To borrow an expression from another place where people are deeply concerned with the custodianship of memory in a materially impermanent culture, people and events can become forgotten when "there's no one left who remembers" (Evans 2007, 83; discussing the semantics of memory in Dalabon). At this point, the old coconut palms, standing in dense regrown rain forest or in the abandoned clearings of old hamlets, provide the most durable evidence of human presence in the self-revegetating landscape of southern New Guinea-exactly what memory they grew has been forgotten, but the fact that someone wanted to create a memory remains. The planting of coconuts in Bimadbn and surrounding areas, then, is an important means of placing memories into the botanical environment-the "growing memories" of these trees in turn depending on human interpreters to tell their stories.

I THANK the organizers of the eleventh European Society for Oceanists conference, Eveline Dürr, Sina Emde, and Philipp Schorch, for their invitation to present this work, as well as for their helpful comments on the draft manuscript, and Candice Steiner for numerous stylistic improvements. I also thank the audience members for their feedback and two anonymous reviewers for further useful comments. My work would not have been possible without the hospitality and teachings of my friends in the village of Bimadbn, and I thank them-particularly 
Jimmy Nébni, Goe Dibod, Doreen Minung, Mary Dibod, and Michael Binzawafor their perceptive help, as well as the clan language committees in Bimadbn, Bévdvn, Govav, and Dimsisi for carrying out the interviews and Eri Kashima and Dineke Schokkin for their work on the Nmbo and Idi material. For their financial support, I thank the Australian Research Council (ARC) (Grants: "Languages of Southern New Guinea" and "The Wellsprings of Linguistic Diversity"); the Volkswagen Foundation (DoBeS project "Nen and Tonda"); the Alexander von Humboldt Foundation (Anneliese Maier Forschungspreis); and the ARC Centre of Excellence for the Dynamics of Language. For their input on the initial presentation and paper, I thank Chris Ballard, Penny Johnson, Darja Hoenigman (for video subtitling), and Borut Telban, and for subsequent useful discussions regarding coconuts in the Pacific, I thank Sophie Caillon and Margaret Rodman.

\section{Notes}

I As Ballard explained, "While Koselleck obviously allows for the possibility of cross-cultural variation in temporalities, it is a field that he leaves largely unexplored" (2018).

2 Following standard practice, by New Guinea I mean the whole island, of which the modern nation of Papua New Guinea constitutes the eastern half. By "southern New Guinea," I refer to the region stretching from the Fly River mouth in the east to the Maro River mouth in the west; it is a region that is geographically and culturally defined, straddling two modern nations, but has no official status.

3 In Nen, the term sakr refers to the palm Caryota rumphiana; it seems plausible that this is the same species Mary Ayres was referring to (1983).

4 According to Christian Döhler, this is probably wäsü, or Ficus elastica (pers comm).

5 Williams spelled Äkämära as Wekamara (see, eg, I936, 53 ).

6 See, for example, Caillon 20 I I; Rodman I987. Discussions of coconut trees scattered throughout Williams's ethnography, based on fieldwork in the I920s, indicate that coconuts were already an established feature of local life by then; he signally failed to mention copra as an economic product and already in the r 920 s indicated that coconut trees were village markers (Williams I936, 220-22I, I2). On the other hand, Bimadbn elders told me that long ago, when the ancestors arrived, there were no coconuts and that the coconuts had come from the coast, having been brought there by people from the Pacific Islands-which suggests they arrived around the mid-nineteenth century. Colonial-era sketches from Darnley Island, Torres Straits, in the I 84 os already show mature coconuts growing there. In terms of erstwhile commercial plans, people in Bimadbn told me that 
in the I960s an Australian didiman (agricultural extension officer) organized the planting of a special plot of coconuts with a view to eventual copra production. Though the trees still stand, they have never been used commercially.

7 One of the questions often asked was, "Who do you think will live longeryou or the coconut?" The answer was inevitably, "The coconut—for my children and grandchildren."

8 That is, the same interview was conducted first in one language and then in another. There is a high level of conformity between the content and length of the two interviews in such cases.

9 See Evans and Miller 2016 for a discussion of Nen phonology, including orthography.

Io For example, in CR3 I, Goe Dibod tells about a coconut in the forest near Bimadbn, which survives as a marker of a garden that his father established around thirty-five years ago.

I I Compare the distinction described by Markus Schindlbeck among the Sawos (Sepik): "Sago areas, which already in the time of the ancestors belonged to the same clan and are thus 'old' property, are described as təsəmblama nyaitmo ngwaimo nosu, 'Sago swamps of the fathers and grandfathers,' and delimited from other sago areas, which only pass later into being clan property. These latter are numbungi nosu sago, 'swamps of the enemy"' (1978, 323; translation mine).

I 2 Original: "l'arbre aux mille usages domestiques."

I 3 Nen and other languages of the region lack words for coconut life stages. This contrasts with the situation for most Oceanic languages, which possess up to fourteen words for different life stages of the coconut (Ross and Evans 2008). This difference may reflect the very different time depths for use and growth of the coconut, as between Austronesian and southern Papuan cultures.

I 4 Identification codes like CRI 8 identify the particular interviews. These are archived in the Pacific and Regional Archive for Digital Sources in Endangered Cultures (PARADISEC) along with other materials from the project. Transcriptions and translations are by myself for Nen and by Dineke Schokkin for Idi. To access the interviews and for additional information, visit https://catalog.paradisec.org .au/collections/LSNGo2 (DOI: I0.4225/72/56E978Fi6EBD4).

I 5 Bebedeben is Williams's rendition, and Bevdvn is Kashima's.

I 6 For similar uses in the Sepik, consider this description of the Ambonwari by Borut Telban: "Caring about the future of his children, a father divides coconut and betel nut palms and banana plants and piper betel vines between his sons and daughters" (I998, I25-I26).

I7 Telban described similar practices among the Ambonwari in the Sepik involving the planting of betel nut, banana, or coconut over young women's menstrual pads as a temporary measure to prevent pregnancy until they are ready for marriage (I998, 20I).

I 8 An interesting grammatical reflex of this is that only in the description 
of this ritual, out of all of the coconut interviews I have transcribed so far, does one see the use of the "large plural" on verbs - an unusual Nen category used to express especially large numbers of participants (Evans 20I7).

I9 Among the Ambonwari, this erasure of a planted past is also found in cases of bereavement: if a young, unmarried child dies, the father and his brothers may in their grief cut down all the palms, trees, and other plants that belonged to the deceased child (Telban I998, I25-I26).

\section{References}

Ayres, Mary

I983 This Side, That Side: Locality and Exogamous Group Definition in the Morehead Area, Southwestern Papua. PhD dissertation, University of Chicago.

Ballard, Chris

2018 Pacific Futurities. In Pacific Futures: Past and Present, edited by Warwick Anderson, Miranda Johnson, and Barbara Brookes. Honolulu: University of Hawai'i Press.

Ballard, Chris, and Meredith Wilson

20I4 Pacific Monumentalism. Studies in Global Archaeology 20:77-98.

Battaglia, Debbora

I990 On the Bones of the Serpent: Person, Memory, and Mortality in Sabarl Island Society. Chicago: University of Chicago Press.

Bell, Joshua A

2006 Losing the Forest but not the Stories in the Trees: Contemporary Understandings of the Government Anthropologist F.E. Williams' I922 Photographs of the Purari Delta, Papua New Guinea. Journal of Pacific History 4I (2): I9I-206.

Bell, Joshua A, Paige West, and Colin Filer, editors

2OI5 Tropical Forests of Oceania: Anthropological Perspectives. Canberra: ANU Press.

Berliner, David

2005 The Abuses of Memory: Reflections on the Memory Boom in Anthropology. Anthropological Quarterly 78 (I): I97-2II.

Caillon, Sophie

20I I Ethnobotanique du cocotier (Cocos nucifera L.) sur l'île de Vanua Lava (Vanuatu). Journal de la Société des Océanistes I33:333-35I.

Evans, Nicholas

2007 Standing Up Your Mind: Remembering in Dalabon. In The Language of Memory in a Crosslinguistic Perspective, edited by Mengistu Amberber, 67-96. Amsterdam: John Benjamins. 
2017 Quantification in Nen. In Handbook of Quantifiers in Natural Language: Volume II, edited by Edward L Keenan and Denis Paperno, 573-609. Studies in Linguistics and Philosophy 97. Basel: Springer International Publishing.

Evans, Nicholas, Wayan Arka, Matthew Carroll, Christian Döhler, Eri Kashima, Emil Mittag, Volker Gast, Dineke Schokkin, Kyla Quinn, Philip Tama, Charlotte Van Tongeren, Bruno Olson, and Jeff Siegel

2017 The Languages of Southern New Guinea. In The Languages and Linguistics of New Guinea: A Comprehensive Guide, edited by Bill Palmer, 64I-774. Berlin: Walter de Gruyter.

Evans, Nicholas, and Julia Colleen Miller

2016 Nen. Journal of the International Phonetic Association 46 (3): 33 I349 .

Forty, Adrian, and Susanne Küchler, editors

I999 The Art of Forgetting. Oxford: Berg.

François, Alexandre

2012 The Dynamics of Linguistic Diversity: Egalitarian Multilingualism and Power Imbalance among Northern Vanuatu Languages. International Journal of the Sociology of Language 2I 4:8 5-I IO.

Harrison, Simon

2004 Forgetful and Memorious Landscapes. Social Anthropology I2 (2): I35-I 5 I.

Haudricourt, André-Georges

I96I Richesse en Phonèmes et Richesse en Locuteurs. L'Homme I (I): 5-IO.

Horowitz, Lea Sophie

200I Perceptions of Nature and Responses to Environmental Degradation

Knauft, Bruce M in New Caledonia. Ethnology 40 (I): 237-250.

I993 South Coast New Guinea Cultures: History, Comparison, Dialectic. Cambridge, uk: Cambridge University Press.

Koselleck, Reinhart

2002 The Practice of Conceptual History: Timing History, Spacing Concepts. Stanford, ca: Stanford University Press.

2004 Futures Past: On the Semantics of Historical Time. New York: Columbia University Press.

Lipset, David M

20I4 Place in the Anthropocene: A Mangrove Lagoon in Papua New Guinea in the Time of Rising Sea-levels. HAU: Journal of Ethno-

Morphy, Howard graphic Theory 4 (3): 2 I 5-243.

I995 Landscape and the Reproduction of the Ancestral Past. In The 
Anthropology of Landscape: Perspectives on Place and Space, edited by Eric Hirsch and Michael O'Hanlon, I84-209. Oxford: Clarendon Press.

Rival, Laura M, editor

I998 The Social Life of Trees: Anthropological Perspectives on Tree Symbolism. Oxford: Berg.

Rodman, Margaret

I987 Masters of Tradition. Consequences of Customary Land Tenure in Longana, Vanuatu. Vancouver: University of British Columbia Press.

Ross, Malcolm, and Bethwyn Evans

2008 The Coconut Palm. In The Lexicon of Proto Oceanic 3: Plants, edited by Malcolm Ross, Andrew Pawley, and Meredith Osmond, 355-387. Canberra: Pacific Linguistics.

Rumsey, Alan

$200 \mathrm{I}$ Tracks, Traces, and Links to Land in Aboriginal Australia, New Guinea, and Beyond. In Emplaced Myth: Space, Narrative, and Knowledge in Aboriginal Australia and Papua New Guinea, edited by Alan Rumsey and James F Weiner, I9-42. Honolulu: University of Hawai'i Press.

Rumsey, Alan, and James F Weiner, editors

200I Emplaced Myth: Space, Narrative, and Knowledge in Aboriginal Australia and Papua New Guinea. Honolulu: University of Hawai'i Press.

Santos-Granero, Fernando

I998 Writing History into the Landscape. Space, Myth, and Ritual in Contemporary Amazonia. American Ethnologist 25:I28-I48.

Schindlbeck, Markus

I978 Sago bei den Sawos (Mittelsepik, Papua New Guinea). Basel, Switzerland: Ethnologisches Seminar der Universität und Museum für Völkerkunde.

Stewart, Pamela, and Andrew Strathern

2000 Naming Places: Duna Evocations of Landscape in Papua New Guinea. People and Culture in Oceania I6:87-107.

2003 Introduction. In Landscape, Memory and History: Anthropological Perspectives, edited by Pamela Stewart and Andrew Strathern, I-I 5 . London: Pluto Press.

Telban, Borut

I998 Dancing through Time: A Sepik Cosmology. Oxford: Oxford University Press.

van Baal, Jan

I966 Dema: Description and Analysis of Marind-Anim Culture. The Hague: Martinus Nijhoff. 
Weiner, James F

I99I The Empty Place: Poetry, Space, and Being among the Foi of Papua New Guinea. Bloomington: Indiana University Press.

Williams, Francis E

I936 Papuans of the Trans-Fly. Oxford: Clarendon.

\begin{abstract}
From cathedrals to dreaming sites, every culture needs its monuments. But the landscape and built culture of southern New Guinea conspire to erase physical memory. In the ever-changing environment of mud, plants, and water, there are no rock formations to serve as durable traces of the past. Wooden houses decay within a decade or two. Garden clearings grow back after a few years. The savannah edge, if not maintained by regular bushfires, is soon recolonized by forest. Against this mutable environment, stability of external memory is given by the coconut trees planted anywhere a plant can grow: beaches, swiddens, old villages, house yards. Almost every coconut palm serves as a tab (sign) - a reminder of stories of garden clearings, resettlements, disputes, pledges, or intentions. For most, there are individuals with the special knowledge needed to tell their stories. These trees form an arboreal history anchored in their durability and in the clear symbolic and practical intentions that accompany each planting. In this paper, I illustrate the trees' mnemonic value, drawing on hundreds of interviews conducted by local interviewers in their own languages-Nen, Nmbo, and Idi. Responding to the flexible interactions between each interviewer and interviewee, they cover many topics, from memories of old gardens, abandoned houses, or temporary periods in other villages, through reconciliations, to girl-abducting teenagers and midlife contraceptives. In presenting this corpus of material, I marry linguistic and anthropological analyses to show how a network of communities, linked by marriage and exchange across language boundaries, uses these living monuments to maintain its histories across a broad range of spokespeople.
\end{abstract}

KEYWORDS: coconuts, memory, southern New Guinea, Nen, oral history 